\title{
Studies of Inorganic Anions at Different Depth of Agriculture Soil and its correlation with Ground Water Pollution.
}

\author{
Bharatiy Sharma ${ }^{1}$, Ashu Rani ${ }^{2}$ \\ ' (Department of Chemistry, Modi Institute of Technology, Kota-324001, INDIA) \\ ${ }^{2}$ (Department of Pure and Applied Chemistry, University of Kota, Kota-324005, INDIA)
}

\begin{abstract}
The present research study has been conducted in the vicinity of industrial city, Kota in Rajasthan where six agriculture fields, two each of paddy, soyabean and wheat crops were selected for analysis work.. Chemical fertilizers applied in these fields were mainly urea, diammonium phosphate, zinc sulphate and potassium chloride. Soil samples have been collected from every field at various depths prior to and after the crop as well as during the crop growth $\mathrm{pH}$, E.Ce. and water soluble Nitrate $\left(\mathrm{NO}_{3}{ }^{-}\right)$, Chloride $\left(\mathrm{Cl}^{-}\right)$, Sulphate $\left(\mathrm{SO}_{4}{ }^{2-}\right)$ and Phosphate $\left(\mathrm{PO}_{4}{ }^{3-}\right)$ were estimated in all collected samples. An effort has been made to find the change in soil characteristic of the field before and after the crop.

Ground water quality of rural areas of four major district that is Kota, Baran, Bundi and Jhalawar of Hadoti region of Rajasthan were also assessed to find out correlation between leaching of anions and water pollution.
\end{abstract}

Keywords: Agriculture fields, Chemical fertilizer, Nitrate, Nitrite, Chloride, Sulphate, Phosphate.

\section{Introduction}

Pollution of water bodies is increasing steadily due to rapid pollution growth, industrial proliferation, urbanization and wide sphere of human activity including use of fertilizer for high and better crop yields. Water pollution due to uncontrolled use of nitrogenous and phosphatic fertilizer has become a cause of concern among scientific fraternity (Follet et al., 1991[1] and Singh et al., 2006 [2]). Since the plants often can not utilize all the fertilizer applied to the fields, fertilizer are washed off and find their way into the surface water while downward percolation transport them to subsurface drainage or ground water (Ramos et. al., 2002 [3] )

The leaching of salts are basically the relative mobility or fluidity of water along with salt movement as diffusion of salt is not possible without diffusion of water in saturated soils. One of the worst consequence of leaching from polluted sites as well as from over fertilized agricultural fields during irrigation, rain events and water percolation is contamination of subsurface and ground water (Carefoot and Whalem, 2003[4] ). Leaching may depend on macro porosity of soil (Jonge et al., 2004 [5]) as well as laminar flow of water in cracks and channels found in soils (Wilfried et al., 2006 [6] ). It is also reported to further depend on soil quality, applied water quality, ion exchange (Oster et al., 1972 [7] ), salt solubility initial water content of soil (Verma and Gupta 1989 [8] ), pH (Ernani et al., 1996 [9] ) and temperature etc. in various types of soils.

To meet the ever-increasing demand of the food supply and due to higher cost of biofertilizers application of chemical fertilizers has become an unavoidable need for higher yield and better quality in the present agricultural system adopted all over the world. Application of fertilizers in excess to the crop demand becomes a curse for the ground water eventually in almost all types of agricultural soils.

The use of nitrogen and phosphatic fertilizers at rates higher than the rate uptake by the plants, increase the potential for increased nitrate and phosphate leaching as has been shown by several studies (Singh et al., 2000 [10] ) Collins et al.,1999,[11] Petrovic ,1990 [12]).

Transport of phosphate from over fertilized soil has also been reported to cause eutrophication of lakes and estuaries because even a little amount of $20-30 \mathrm{mg} / \mathrm{l}$ of phosphate in surface runoff can stimulate phytoplankton growth ( Denied et al.,[13] 1998, Broesch et al., 2001 [14]). Inorganic phosphates such as mono and diammonium hydrogen phosphate, tri-calcium phosphate, super phosphate, calcium metaphosphate etc. are widely applied as fertilizers and over fertilize most of the agricultural lands in developed countries.

( Barberis et al., 1996[15], Carefoot and Whalem, 2003[4]). As nitrate is a wide spread contaminant of ground and surface water world wide, it posses a potential threat to human health specially to infant causing the condition known as methemoglobinmea (Kross et al., 1993[16] ). Chronic consumption of high level of nitrate may also cause other health problems such as cancer and teratogenic effect, data are inconclusive but cause of concern (Jane at al. 2008[17] ).

The present research study has been conducted in the vicinity of industrial city Kota in Rajasthan, India where six agriculture fields, two each of paddy, soyabean and wheat crop were selected for the soil collection and analysis work. Chemical fertilizer applied in these fields were mainly urea, diammonium phosphate, $\mathrm{ZnSO}_{4}$ and $\mathrm{KCl}$. Soil samples have been collected from every fields prior to and after the crop as well as during the 
crop growth at 15 days interval . PH, E.Ce and water soluble Nitrate $\left(\mathrm{NO}_{3}{ }^{-}\right)$, Chloride $\left(\mathrm{Cl}^{-}\right)$, Sulphate $\left(\mathrm{SO}_{4}{ }^{2-}\right)$ and Phosphate $\left(\mathrm{PO}_{4}{ }^{3-}\right)$ were estimated in all collected samples. Beside soil samples, ground water samples collected from rural areas of Hadoti region were also characterized for $\mathrm{pH}$, E.Ce and water soluble, $\mathrm{NO}_{3}{ }^{-}, \mathrm{Cl}^{-}$, $\mathrm{SO}_{4}{ }^{2-}$ and $\mathrm{PO}_{4}{ }^{3-}$ ions to find correlation between leaching of salt and surface and ground water pollution.

\section{Materials and Method}

Soil samples were collected by digging a deep pit.Samples were collected and pour in a begs and labeled according to their depth and field at four different depths of six different points in each field. Samples were collected 2-3 times in a month at every site continuously during entire study period.

Water samples were collected from near by villages of Hadoti region in two different seasons pre monsoon (January) and post monsoon (may).Each sample was collected by acid -washed polythene bottle and analyzed for major ions in the laboratory by employing slandered method.

One year field experiment was setup in the three field of Nanta farm house Kota having area $50 \mathrm{~m}^{2}$. Fertiliser $\mathrm{N}, \mathrm{P}$ and $\mathrm{K}$ were applied as Urea,Di-ammonium phosphate, $\mathrm{ZnSO}_{4}$ and $\mathrm{KCl}$ at seasonal rate $100 \mathrm{~kg}$ per ha, $75 \mathrm{~kg}$ per ha, $30 \mathrm{~kg}$ per ha and $80 \mathrm{~kg}$ per ha respectively. Three major crops viz. paddy, soyabean and wheat were selected for the study.

Sample collection were carried out before, during crop growth of wheat, Soya bean and Paddy after 15 days intervals. Shoot lengths of the plant were measured accurately during each sampling. Agriculture soil samples were collected by digging a deep pit., samples were collected and pour in bags and labeled according to their depth. Soil profile of the soil samples collected at four different depth studied by Nanta agriculture farm Kota, Rajasthan, India is given below.

As we concentrate more upon the downwards transportation of the fertilizer ions along with percolating water rather than absorption of soluble ions by plant root, data of root and shoot length growth are not presented here. These samples were dried and sieved (Particle Size $=500 \geq \mathrm{r} \geq 250, \theta=0.34 \mathrm{~cm}^{3} \mathrm{~cm}^{-3}$ ) and analyzed for above said ions using batch method. The water of study area are relatively shallow lying ground water between the surface and approximately 3 meter depth. The rise of this ground water is directly related to the monsoon, canal seepage and deep percolation, both soil and water samples were analyzed in laboratory using standard APHA method (2000[18]).

\section{Result and Discussion}

Soil profile of the soil samples collected at four different depth studied by Nanta agriculture farm Kota is given below.

\subsection{Soil Profile}

3.1.1 Depth (0-10cm): Dark brown (10YR3/3) moist, clay loam texture, very fine weak sub-angular blocky structure very friable consistency, soft and crumbly when dry and slightly stickey when wet, medium and fine root penetration, slightly effervescent with acid application, medium and fine discontinuous, pores, moderately permeable.

3.1.2 Depth (10-35): Dark brown(10YR3/3) clay loam texture, fine weak moderate subangular blocky structure, friable consistency, crumbly when dry and slightly effervescent with acid application, medium and fine discontinuous pore, moderately permeable $\mathrm{pH} 8.0$ gradual smooth boundary.

3.1.3.Depth (35-80): Dark brown(10YR3/3) moist, clay loam texture, very fine weak sub-angular blocky structure slightly firm consistency moderately hard when dry and moderately sticky when wet, fine root

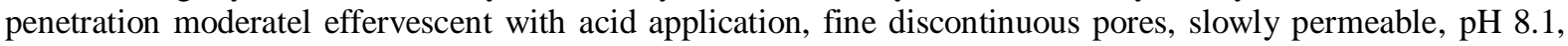
gradual smooth boundary.

3.1.4.Depth (80-100): Dark brown (10YR3/3) moist, clay ,texture, medium moderate angular blocky structure, moderately firm consistency, moderately hard when dry and moderate stickey when wet.

\section{$3.2 \mathrm{pH}$}

Results of $\mathrm{pH}$ determination are given in the table-1. Results depicts the $\mathrm{pH}$ value of each field where three crops i.e. paddy, soyabean and wheat crop were grown. $\mathrm{pH}$ determination is carried out at 15 days intervals before, after and during the cropgrowth. In case of paddy and wheat net decrease in $\mathrm{pH}$ was measured in the top soil whereas in soyabean fields net increase in $\mathrm{pH}$ is found in top soil $(10-15 \mathrm{~cm})$. The maximum change in $\mathrm{pH}$ of all the fields is observed at 30-45 cm depth. Change in field condition is the difference in first and last observation of the field. 
Table -1: Depth wise distribution of pH during crop growth.

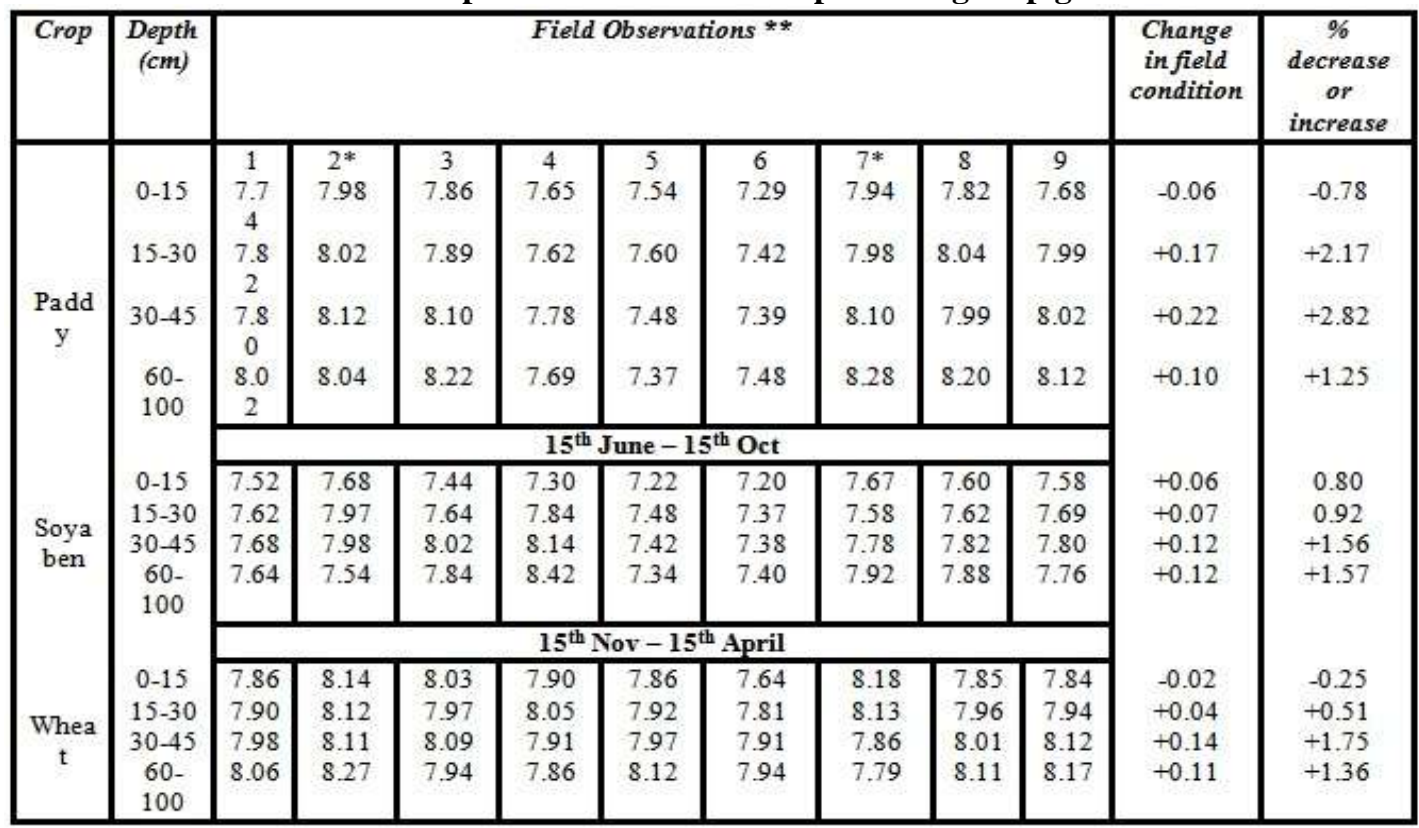

*Time of fertilizer application

**Field observation were made at 15 days intervals.

\subsection{Electrical Conductivity (E.Ce)}

Results of electrical conductivity variation are given in table-2 . In paddy fields net increase in E.Ce is noted at all depth. While in soyabean E.Ce is increased at depth( 0-15) cm. In wheat field E.Ce is increased by $7.96 \%$ at $(0-15) \mathrm{cm}$ and by $13.36 \%$ at $15-30 \mathrm{~cm}$.

\subsection{Nitrate $\left(\mathrm{NO}_{3}{ }^{-}\right)$}

Results of field nitrate variation with crop growth are shown in fig. 1, for Paddy field .Overall \% increase is observed below $60 \mathrm{~cm}$ depth while net decreased is noticed at $0-45 \mathrm{~cm}$ depth in paddy field. In Soyabean and wheat field net nitrate increase was below $30 \mathrm{~cm}$ time of fertilizer application. It is reported by various studies that nitrate variation in agriculture field not only depend on the plant uptake and leaching but several other processes such as nitrification denitrification as well as evaporation of $\mathrm{NH}_{3}$ ( Nakasone et al., 2004[19]). However continuous change in the value with depth confirms solubility and movement of nitrate in the soil.

Table -2: Depth wise distribution of E.Ce during crop growth.

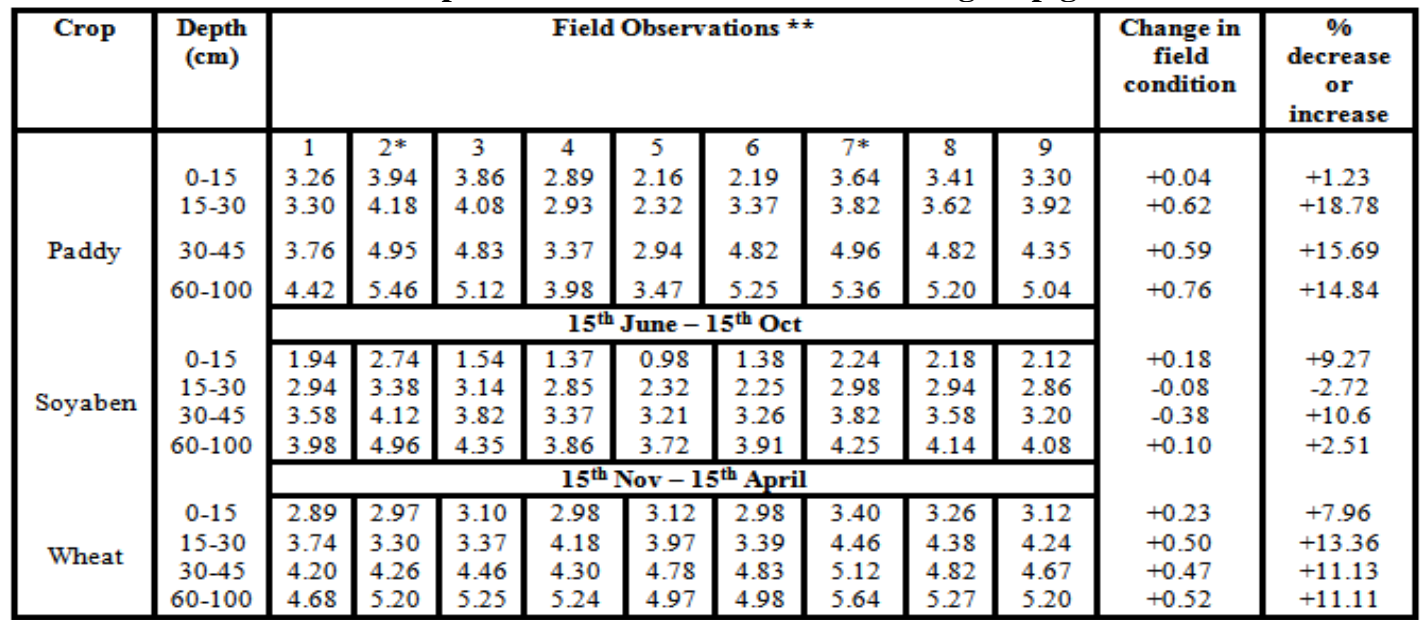

* Time of fertilizer application

**Field observation were made during June to October at 15 days intervals. 


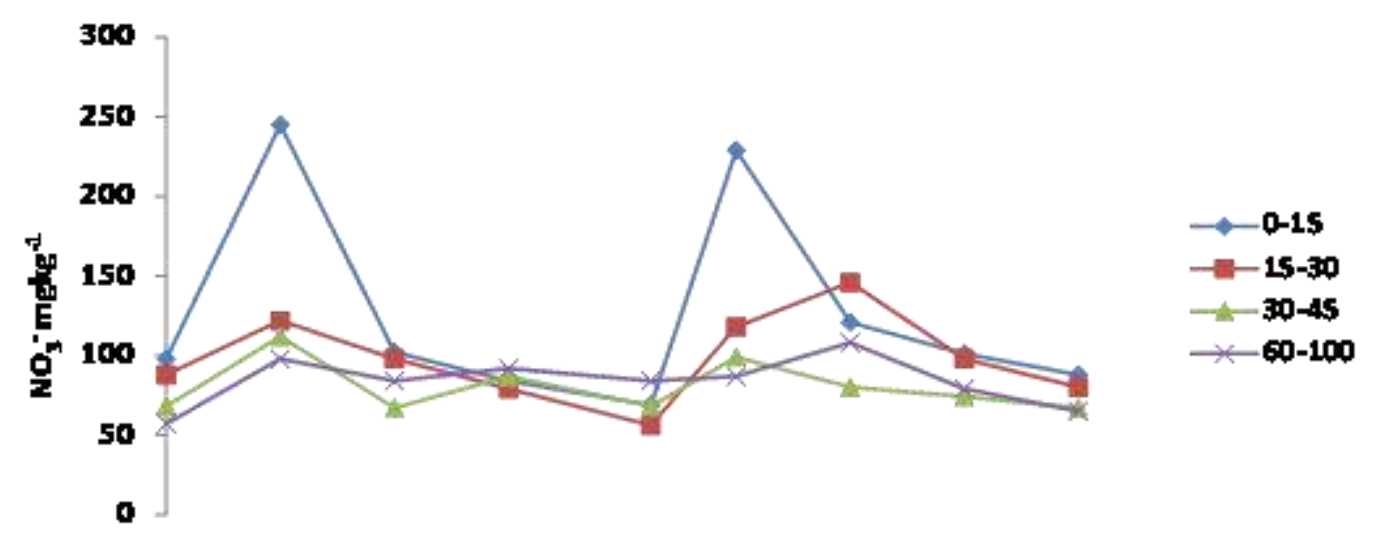

Figure 1 - Change in field Nitrate concentration (Extracting water) with crop growth for Paddy crops at 15 days interval at various depth of field .

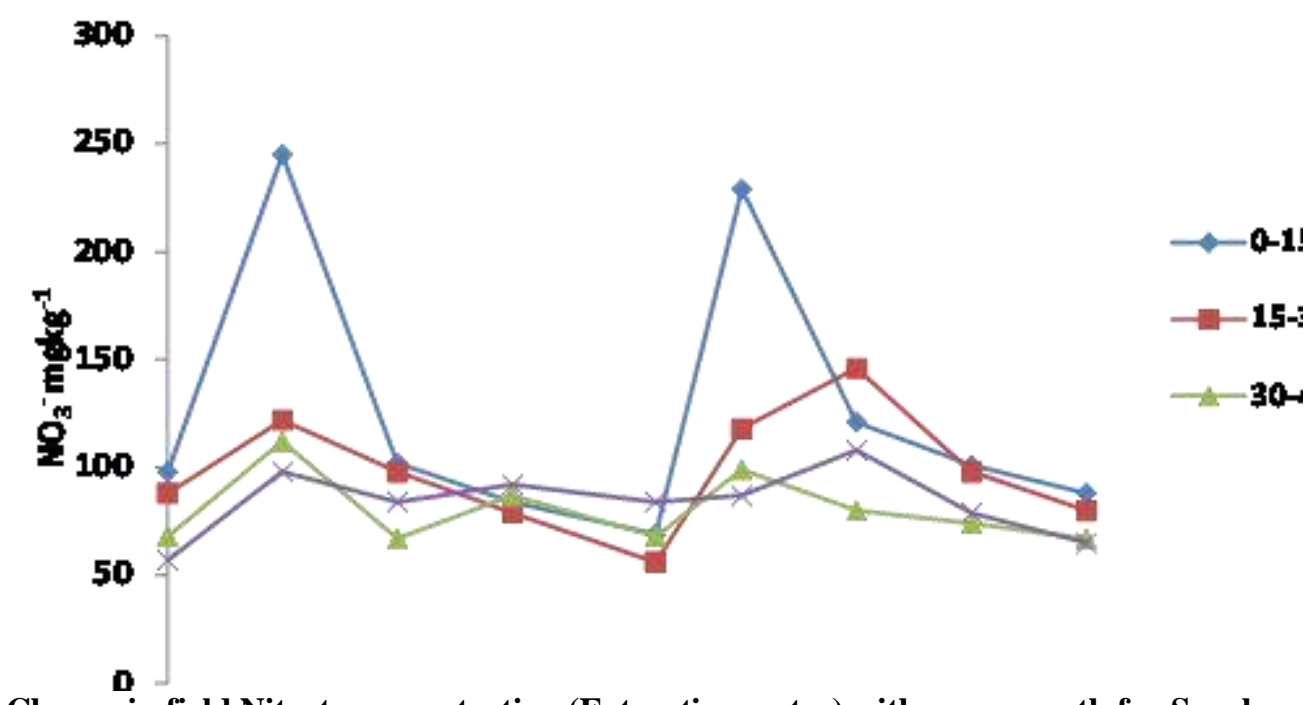

Figure 2 - Change in field Nitrate concentration (Extracting water) with crop growth for Soyabean crops at 15 days interval at various depth of field .

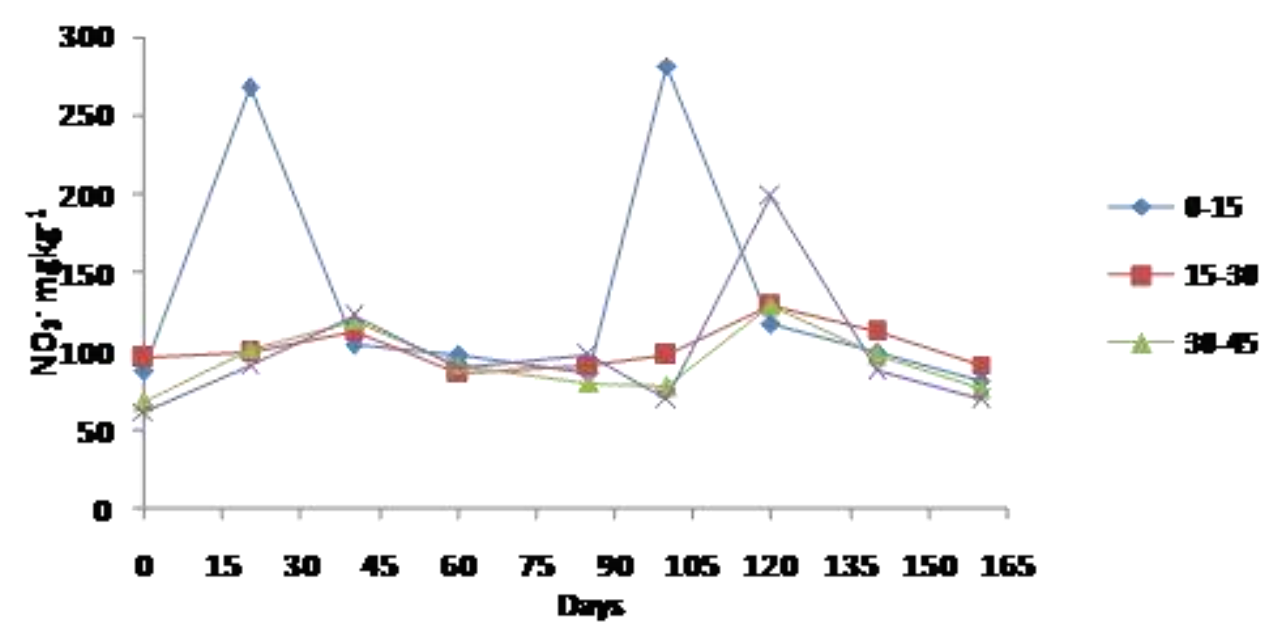

Figure 3 - Change in field Nitrate concentration (Extracting water) with crop growth for Wheat crops at PHOSPHATE $\left(\mathrm{PO}_{4}{ }^{3-}\right.$ ) 15 days interval at various depth of field .

Results of phosphate analysis are given in table 4. Phosphate concentration in all the agriculture fields is found very high in comparison to other ions. 
Phosphate is found to increase below $15 \mathrm{~cm}$ depth in paddy and wheat fields while in soyaben net increase is observed below $30 \mathrm{~cm}$. A maximum increase of $15.6 \mathrm{~cm} \%$ is observed in wheat fields below $45 \mathrm{~cm}$.

Table- 3: Depth wise distribution of $\mathrm{PO}_{4}{ }^{3-}$ during crop growth.

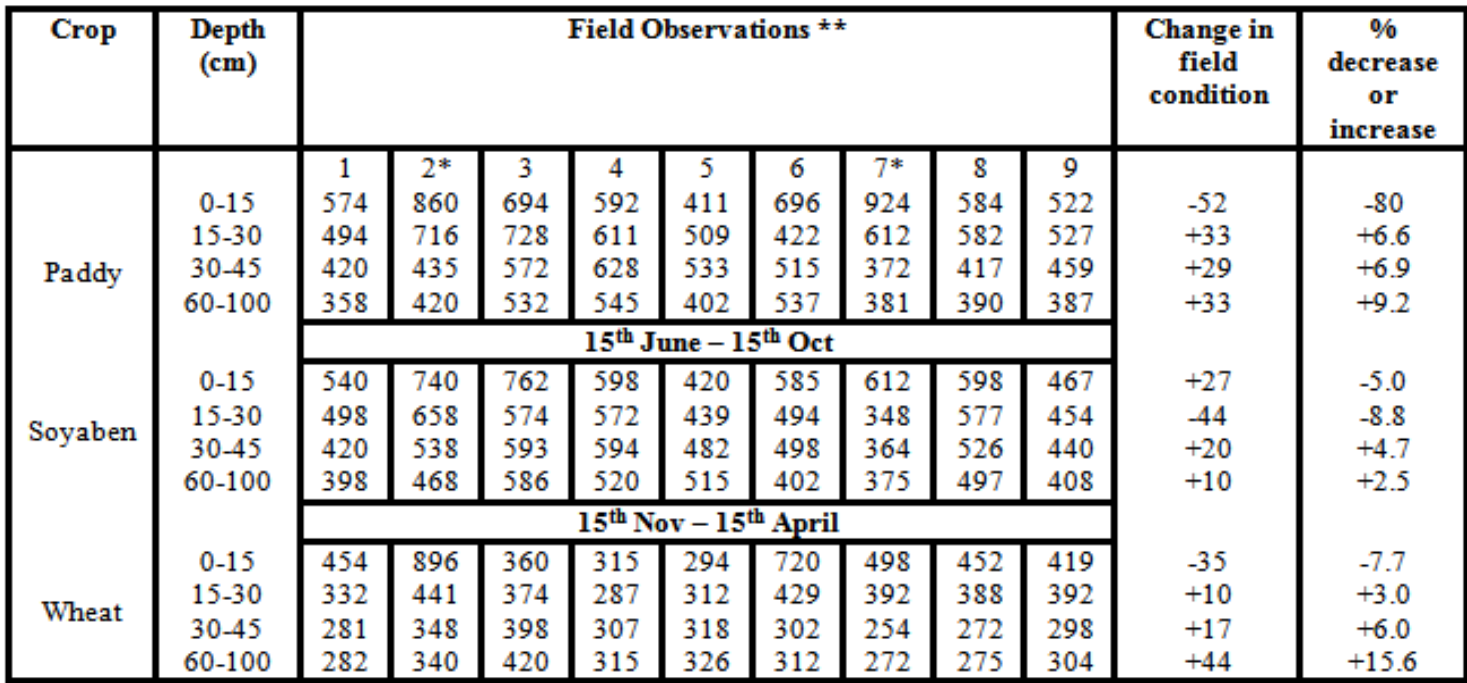

* Time of fertilizer application

**Field observation were made during June to October at 15 days intervals.

\section{SULPHATE $\left(\mathrm{SO}_{4}{ }^{3-}\right)$}

Results at sulphate estimation in agriculture fields are present in table 4 . Similar to other fertilizer ions transport of soluble sulphate is observed below $30 \mathrm{~cm}$ in case of paddy and soyabean while in wheat increase is in region $30-45 \mathrm{~cm}$. In case of sulphate percentage field change is below $10 \%$ in all cases.

\section{CHLORIDE ( $\left.\mathrm{Cl}^{-}\right)$}

Field chloride levels are analyzed along with crop growth result are presented in table 5 , contrary to other ions, $\mathrm{Cl}^{-}$in paddy fields is found to increase at the surface level and decreases below $15 \mathrm{~cm}$ depth but in case of soyabean and wheat a slight net decrease in $\mathrm{Cl}^{-}$is observed at all depths there is not much change in the field chloride values. Previous study (Minaxi 2005 ) of leaching kinetics of $\mathrm{Cl}^{-}$in soil of the region reports that alkaline soil under study does not have any binding or adsorption capacity for $\mathrm{Cl}^{-}$. This lead to complete removal of $\mathrm{Cl}^{-}$from fields along with other fertilizer ions.

Table- 4: Depth wise distribution of $\mathrm{SO}_{4}{ }^{2-}$ during crop growth.

\begin{tabular}{|c|c|c|c|c|c|c|c|c|c|c|c|c|}
\hline Crop & Depth & \multicolumn{9}{|c|}{ Field Observations ** } & Change in & \\
\hline \multirow{5}{*}{ Paddy } & \multirow{6}{*}{$\begin{array}{c}0-15 \\
15-30 \\
30-45 \\
60-100\end{array}$} & 1 & $2 *$ & 3 & 4 & 5 & 6 & $7 *$ & 8 & 9 & & \\
\hline & & 101 & 190 & 188 & 148 & 99 & 171 & 120 & 109 & 97 & -4 & -3.9 \\
\hline & & 98 & 178 & 157 & 194 & 102 & 140 & 109 & 112 & 104 & -6 & +6.1 \\
\hline & & 88 & 104 & 166 & 150 & 98 & 124 & 118 & 108 & 99 & +10 & +8.8 \\
\hline & & 102 & 99 & 120 & 142 & 128 & 108 & 129 & 99 & 108 & +6 & +5.8 \\
\hline \multirow{6}{*}{ Soyaben } & & \multicolumn{9}{|c|}{$15^{\text {th }}$ June $-15^{\text {th }}$ Oct } & & \\
\hline & \multirow{5}{*}{$\begin{array}{c}0-15 \\
15-30 \\
30-45 \\
60-100\end{array}$} & 98 & 128 & 112 & 97 & 89 & 132 & 118 & 108 & 92 & -6 & -6.12 \\
\hline & & 87 & 98 & 94 & 92 & 102 & 99 & 129 & 99 & 82 & -5 & -5.7 \\
\hline & & 82 & 87 & 99 & 87 & 112 & 88 & 115 & 85 & 88 & +6 & +7.3 \\
\hline & & 78 & 76 & 102 & 94 & 99 & 82 & 120 & 102 & 82 & +4 & +5.1 \\
\hline & & \multicolumn{9}{|c|}{$15^{\text {th }}$ Nov $-15^{\text {th }}$ April } & & \\
\hline \multirow{4}{*}{ Wheat } & $0-15$ & 91 & 136 & 113 & 99 & 86 & 148 & 122 & 108 & 84 & -7 & -7.6 \\
\hline & $15-30$ & 92 & 122 & 134 & 107 & 62 & 98 & 137 & 98 & 86 & -6 & -6.5 \\
\hline & $30-45$ & 82 & 98 & 128 & 98 & 78 & 89 & 142 & 114 & 89 & +7 & +8.5 \\
\hline & $60-100$ & 86 & 84 & 115 & 88 & 82 & 87 & 148 & 99 & 85 & -1 & -1.1 \\
\hline
\end{tabular}

* Time of fertilizer application

**Field observation were made during June to October at 15 days intervals. 


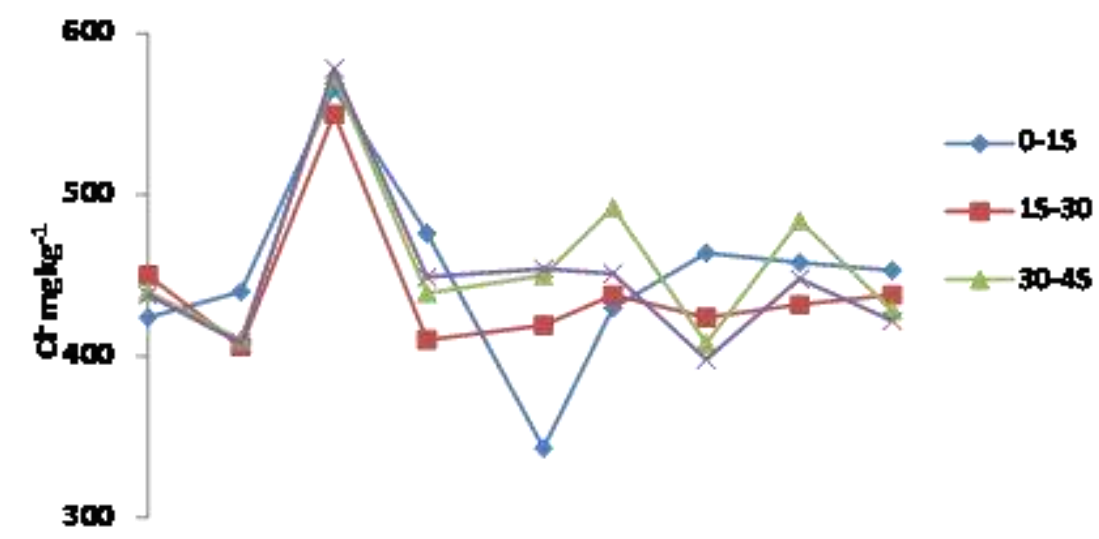

Figure 4 - Change in field Chloride concentration (Extracting water) with crop growth for Paddy crop at 15 days interval at different depth.

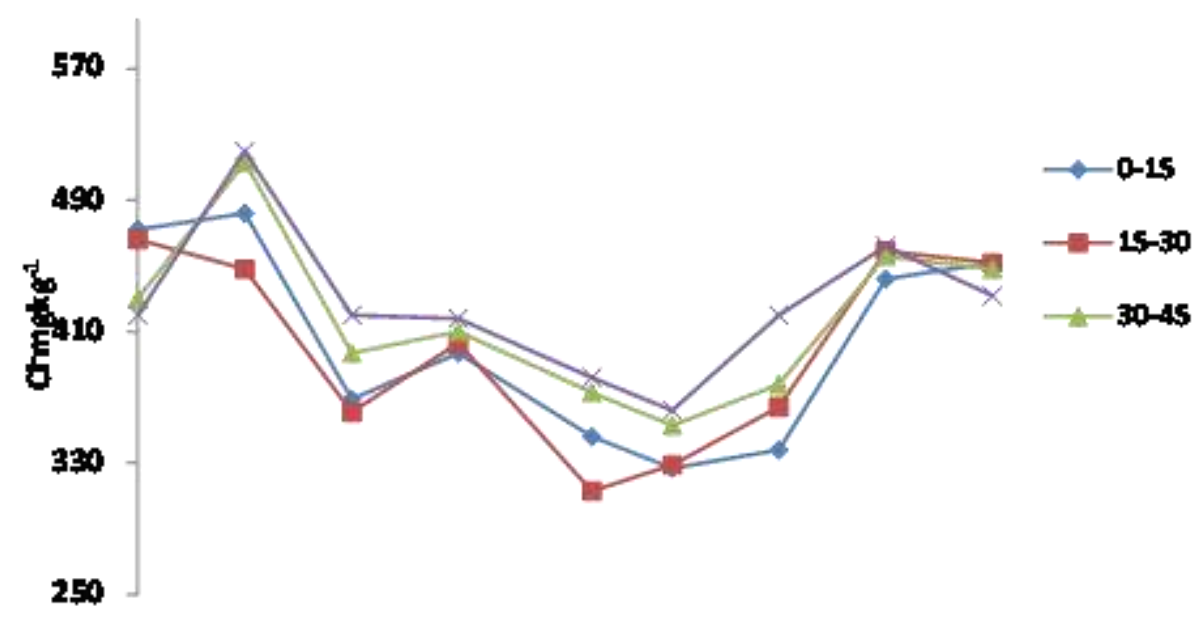

Figure 5 - Change in field Chloride concentration (Extracting water) with crop growth for Soybean crop at 15 days interval at different depth.

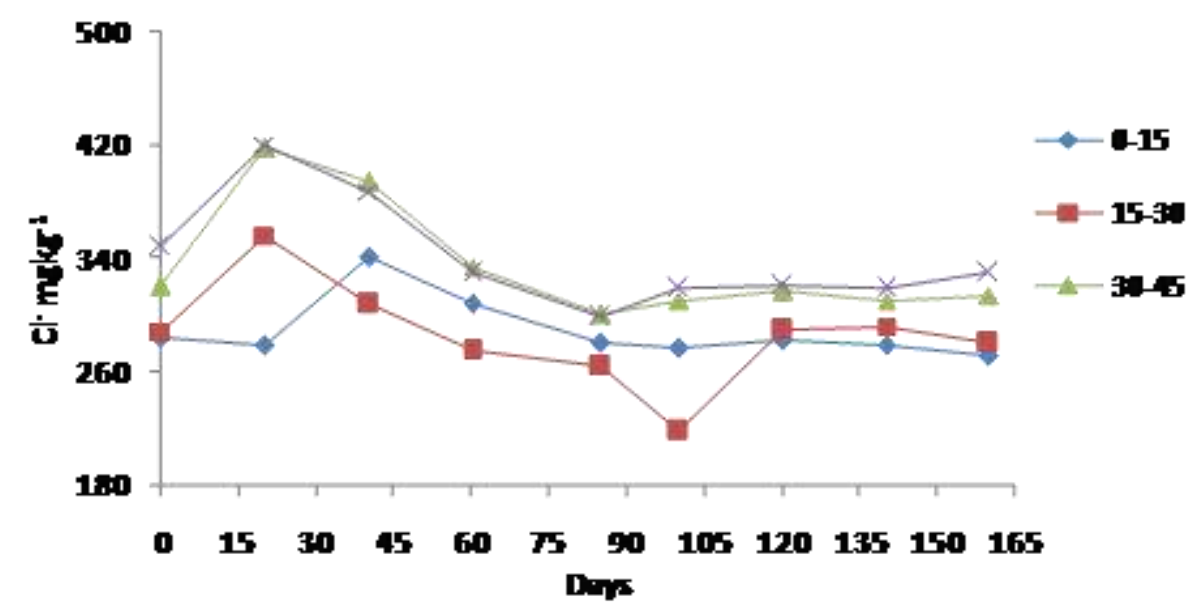

Figure 6- Change in field Chloride concentration (Extracting water) with crop growth for Wheat crop at 15 days interval at different depth.

Ground Water Characterization of Hadoti region of Rajasthan,

The ground water of studied area comprises different villages of Hadoti region of Rajasthan, India. These villages are surrounded by agriculture fields where chemical fertilizers are used to improve the productivity. 
Water sample taken for the study are surface water and under ground water of approximately 3 metre depth. The rise of this ground water is directly related to the monsoon, canal seepage and deep percolation . Ground water was monitored at several rural locations with in the Chambal command area and other parts of the Hadoti region. Result of analysis of underground water quality of different villages of Hadoti region of Rajasthan presented in table 5 .

Table-5 Average Ground Water Quality of different Villages of Hadoti region of Rajasthan, India.

\begin{tabular}{|c|c|c|c|c|c|c|c|}
\hline Villages & $\mathbf{p H}$ & $\begin{array}{l}\text { Tub. } \\
\text { (NTU) }\end{array}$ & $\begin{array}{l}\text { Cond. } \\
\square \text { s/ cm }\end{array}$ & $\begin{array}{l}\mathrm{Cl}^{-} \\
\mathrm{mg} / \mathrm{l}\end{array}$ & $\begin{array}{l}\mathrm{SO}_{4}{ }^{2-} \\
\mathrm{mg} / \mathrm{l}\end{array}$ & $\begin{array}{l}\mathrm{NO}_{3}^{-} \\
\mathrm{mg} / \mathrm{l}\end{array}$ & $\begin{array}{l}\mathrm{PO}_{4}^{-} \\
\mathrm{mg} / \mathrm{l}\end{array}$ \\
\hline $\begin{array}{l}\text { Baran District } \\
\text { Atru } \\
\text { Kishanganj } \\
\text { Mangrol } \\
\text { shahbad }\end{array}$ & $\begin{array}{l}7.3 \\
7.5 \\
7.5 \\
7.4\end{array}$ & $\begin{array}{l}8.9 \\
9.6 \\
6.9 \\
9.7\end{array}$ & $\begin{array}{l}1625 \\
1130 \\
1012 \\
998\end{array}$ & $\begin{array}{l}164 \\
287 \\
152 \\
89\end{array}$ & $\begin{array}{l}123 \\
95 \\
123 \\
89\end{array}$ & $\begin{array}{l}39 \\
35 \\
28.1 \\
49\end{array}$ & $\begin{array}{l}0.9 \\
0.4 \\
1.1 \\
0.6\end{array}$ \\
\hline $\begin{array}{l}\text { Bundi District. } \\
\text { Lalpura } \\
\text { Ganpatpura } \\
\text { Dabi } \\
\text { Bardna }\end{array}$ & $\begin{array}{l}7.7 \\
7.4 \\
7.7 \\
8.0\end{array}$ & $\begin{array}{l}8.7 \\
9.0 \\
6.9 \\
7.5\end{array}$ & $\begin{array}{l}1775 \\
1662 \\
2110 \\
2240\end{array}$ & $\begin{array}{l}179 \\
223 \\
132 \\
234\end{array}$ & $\begin{array}{l}91 \\
122 \\
89 \\
212\end{array}$ & $\begin{array}{l}54 \\
48 \\
41 \\
49\end{array}$ & $\begin{array}{l}0.6 \\
1.4 \\
\text { ND } \\
0.9\end{array}$ \\
\hline $\begin{array}{l}\text { Jhalawar District. } \\
\text { Aklera } \\
\text { Bhawani Mandi } \\
\text { Jhalawar } \\
\text { Jhalarapatan } \\
\text { Piwara }\end{array}$ & $\begin{array}{l}8.9 \\
7.2 \\
7.5 \\
7.6 \\
7.5\end{array}$ & $\begin{array}{l}9.8 \\
6.9 \\
8.6 \\
8.8 \\
9.7\end{array}$ & $\begin{array}{l}3120 \\
2500 \\
1350 \\
990 \\
895\end{array}$ & $\begin{array}{l}143 \\
99 \\
123 \\
72 \\
67\end{array}$ & $\begin{array}{l}329 \\
231 \\
211 \\
77 \\
68\end{array}$ & $\begin{array}{l}383 \\
281 \\
217 \\
160 \\
251\end{array}$ & $\begin{array}{l}0.9 \\
\text { ND } \\
0.7 \\
0.8 \\
1.9\end{array}$ \\
\hline $\begin{array}{l}\text { Kota District. } \\
\text { Alania } \\
\text { Digod } \\
\text { Sultanpur } \\
\text { Gadepan } \\
\text { Kakarwada } \\
\text { Kherli Mahadeet } \\
\text { Simlia } \\
\text { Surela } \\
\text { Bhagawanpura } \\
\text { Fatehpura } \\
\text { Khera Kheri }\end{array}$ & $\begin{array}{l}7.1 \\
7.3 \\
7.8 \\
7.2 \\
8.5 \\
7.4 \\
7.8 \\
7.5 \\
7.6 \\
8.2 \\
7.7\end{array}$ & $\begin{array}{l}10 \\
7.2 \\
12.1 \\
8.5 \\
6.1 \\
10 \\
8.5 \\
9.2 \\
1.5 \\
6.8 \\
10.4\end{array}$ & $\begin{array}{c}1900 \\
1170 \\
935 \\
1828 \\
1400 \\
1820 \\
1200 \\
100 \\
1600 \\
1608 \\
1425\end{array}$ & $\begin{array}{l}105 \\
64 \\
52 \\
57 \\
35 \\
275 \\
54 \\
49 \\
95 \\
50 \\
127\end{array}$ & $\begin{array}{l}750 \\
95 \\
74 \\
840 \\
105 \\
221 \\
35 \\
120 \\
615 \\
218 \\
227\end{array}$ & $\begin{array}{l}11.5 \\
25 \\
11 \\
17 \\
19 \\
75 \\
57 \\
20 \\
170 \\
22.4 \\
43.5 \\
24.3\end{array}$ & $\begin{array}{l}0.7 \\
1.2 \\
0.8 \\
1.4 \\
1.1 \\
\text { ND } \\
\text { ND } \\
1.4 \\
1.5 \\
\text { ND } \\
0.8 \\
1.4\end{array}$ \\
\hline
\end{tabular}

\section{CONCLUSION}

Analytical result of the soil and water analysis carried out during this study clearly shows that excessive addition of the fertilizer in the agriculture field impose significant change in the chemical characteristics of the field soil not only at the point of fertilizer application but on entire profile as shown in Table 1 to 4 and figure 1 to 6 . These.

Observed fluctuations in various parameters have proved movement of soluble fertilizer ions, which may be in downwards direction at a greater rate during the preferential flow of the irrigation water as well as rain water through soil macrospores. Results of the present character encouraged us to find a suitable and more appropriate method of studying leaching rate of fertilizer ions in agriculture fields to generate ground water pollution.

\section{REFERENCES}


[1] Follet R.F., D.R. Keeney and R.M. Cruse, . Managing nitrogen for ground water quality and farm profitability. Soil. Sci. Soc. Am. 63, 1991.

[2] Singh V., Y.Singh, B.Singh and O.P. Neelu,. Distribution and Leaching losses of applied urea-N in sandy, loam and clay loam soils under wet land and upland moisture regimes. J. Ind. Soc. Sci. 54(2),2006, 185-192.

[3] Ramos C, A. Agut and A.L Lindon.,. Nitrate Leaching in Important Crops of the Valecian Community Region. Environ. Poll. Oxford, United Kingdom 118 (2),2002, 215-223.

[4] Carefoot, J.P. and J.K. Whalen,. Phosphorus concentrations in subsurface water as influenced by cropping systems and fertilizer sources. Can. J. Soil Sci. 83, 2003. $203-212$.

[5] Jonge, de W.L. P., G. Rubaek., K. Hschede , and J. Djurhuus.,. Particle Leaching and Particle -Facilitated Transport of Phosphorous at Field Scale. Soil Sci.Soc.Am.J. 3,2004,462-470.

[6] Willfried, W., T. Manfred, T. and P. Uwe.,. Prediction of the P. Leaching Potential of Arable Soils in Areas with high Livestock Densities.2006 ISSN 1673-1581

[7] Oster, J.D., ,L.S. Willardson and G.J Hoffman,. Transactions of American Society of Agriculture Engineers. 15,1972,115.

[8] Verma, S.K. and R.K. Gupta., 1989. Leaching behaviour of saline clay soil under two modes of water application. J. Ind. Soc. Soil. Sci. 37,1989, $803-808$.

[9] Ernani, P.R., O.R.A. Fingueiredo, V. Becegato, and J.A. Aloneido, .Decrease of phosphorus retention in soil with increasing pH. J. Soil Sci. 20 (1),1996. 159-162.

[10] Singh,B., R.M Upadhyay, and O.P Shrivastava.,. Rate of leaching and downwards movement of Urea $-\mathrm{N}^{2}$ and $\mathrm{NH}_{4}{ }^{+}-\mathrm{N}$ in fine and coarse textured soils. J. Ind. Soc. Soil Sci. 48 (2),2000, 371-372.

[11] Collins, S.A. and D.W. Allinson., 1999. Use of anion exchange membranes to asses nitrogen needs of perennial grasslands. Commun. Soil. Sci. Plant Anal. 30,1999, 2267-2282.

[12] Petrovic, A.M., . The fate of nitrogeneous fertilizers applied to turf grass. J of Environmental Quality, 19, 1990,1-14

[13] Danid T.C., A.N. Sharpley and J.L Lemunyon.,1998. Agricultural phosphorus and eutrophication a symposium overview. J.Environ. Qual. 27,1998, 251-257.

[14] Broesch D.F., R.B. Brins Field and R.E. Magnien.,. Chesapeake bay eutrophication scientific understanding, ecosystem restoration and challenges for agriculture. J.Environ. Qual. 30,2001, 303-320.

[15] Barberies E., F.A. Marson., R Scalenghe., A Lammers.,U Schwermann .,A.C. Edwards ., R. Manguire., M.J. Wilson ., A. Delgado and J.Torrent.,. European soils overfertilized with phosphorus. Fertilizer research, 45 (3),1996,199-207.

[16] Kross, B.C., G.R. Hallberg, D.R Bruner, K.Cherry holmes and J.K. Johnson. . The nitrate contamination of private well water in Iowa. Am. J. Public Health. 83,1993, 270-272.

[17] Jane, A. Mc Elroy., Amy Trenthan-Dieltz., John M. Hampton., Andrew J.Bersch., Ronald, E. Gargnon., Marty, S. Kanarek., and A. Polly . Newcomb, Nitrate -Nitrogen. exposure from drinking water and colorectal cancer risk for rural women in wisconsin, USA. Journal of water and health. 6,(3),2008, 399-409.

[18] APHA.,. Standard methods for estimation of water and waste water (20 ${ }^{\text {th }}$ edn.) (American Public Health Association, Washington D.C.,2000).

[19] Nakasone, H., M.A. Abbas and H. Kuroda,. Nitrogen transport and transformation in packed soil columns from paddy fields. Paddy and Water Environment 2,2004, 115-124. 